\title{
Harjuna-Keratarupa Dance Development
}

\author{
Dwiyasmono \\ Institut Seni Indonesia Surakarta, Indonesia
}

\begin{abstract}
Harjuna-Keratarupa was composed first in 1995 to prepare dance performances by ISI Surakarta lecturers to increase the number of performance materials at this art institute. This dance was unique because its variety of movements incorporate Yogyakarta-style dance movements into its presentation structure so that this dance has its level of difficulty.
\end{abstract}

Keywords: Harjuna-Keratarupa, Dance, ISI Surakarta

DOI: $10.7176 / \mathrm{ADS} / 96-03$

Publication date: November $30^{\text {th }} 2021$

\section{Introduction}

Tradition according to the popular dictionary is hereditary (2001: 756), while traditional dance is a dance that is passed down from generation to generation from the palace. Traditional dances still use the standards that have been determined by the previous dance masters. In particular, the traditional dances of the Surakarta style, including the traditional palace dances, are the dances inherited from our ancestors, "which cannot be changed." The dance is believed to be yasan dalem (the king's creation), so it is believed to be a royal heirloom. In the past, all dances in the palace were created by the king. This happens because the palace adheres to the concept of dewaraja, which sees the king as having the same position as a god.

In the palace, dance is a form of culture that influences the life of the king and the royal family. This can be seen in the Bedaya dance and Srimpi dance. In the Surakarta Palace, the Bedhaya and Srimpi dances have been living and developing for a long time, which functioned as a form of personality and etiquette education for the children of the nobility and sentana (royal relatives).

Discussions about traditional dances cannot be separated from the development of these dances. Some factors influence the emergence of developments and changes in society, one of which is innovation. Heni Prahaningrum stated that:

Innovation is another word for renewal or new changes. Innovation is the introduction of new, better ways. Innovation is limited to the notion of efforts that are made intentionally to take advantage of new changes (Prahaningrum, 2009:10).

This theory emphasizes that currently many traditional palace dances are developing because of innovations made by choreographers. This innovation is one of the foundations for development. One example is the Harjuna-Keratarupa Dance which was composed in 1995.

Harjuna-Keratarupa is a form of Surakarta-style dance that has the dance character of putra alus (pliantmale). Harjuna-Keratarupa is danced by two male dancers who are characterized by the character of the putra luruh (delicate) and the putra lanyap (agile). This dance is taken from the Mahabharata story in one of the episodes of Arjuna Wiwaha which means Harjuna's marriage. Harjuna-Keratarupa featured two characters, namely Begawan Ciptaning (Harjuna) and Raden Keratarupa.

This dance was first performed on April 15, 1995 at Pendhapa Ageng ISI Surakarta, danced by Dwiyasmono who played Harjuna and Matheus Wasi Bantolo as Keratarupa.

The uniqueness of this dance is in the variety of movements that incorporate Yogyakarta-style dance movements into its presentation structure so that this dance has its level of difficulty. In addition, this dance has a musical accompaniment structure that emphasizes more on describing the atmosphere to stimulate the emotions built by the dancers. Therefore, dancers with skilled skills are needed to deliver a good performance.

Based on the description above, the formulation of the problem obtained is "Why is the HarjunaKeratarupa dance developing?"

\section{Idea in Creating the Harjuna-Keratarupa Dance}

Harjuna-Keratarupa dance tells about the conflict between Harjuna and Keratarupa. Before created this dance, the choreographer created other works including the Karno Tandhing Dramatari (dance-drama) in 1986, the Pasihan Regawa Prasetyasmara Dance in 1991, the Solah Dance in 2002, and an offering in 2012 for the ISI Surakarta Anniversary.

The choreographer is consistent with dances that was taken from the wayang story. As Rusliana said that:

The background story underlies or as a source in selecting and determining the image and at the same time the theme of the dance. In connection with the peculiarities of this wayang dance, the conception concerns the background of the wayang story and has a definite picture and theme (Rusliana, 2001:26). 
The creation of this dance begins with the choreographer who is involved in a dance drama entitled Arjuna Wiwaha at the Kasunanan Hadiningrat Palace. The choreographer was interested in one of the battle scenes between Harjuna and Keratarupa. This dance is based on the Mahabharata story wherein this story there is a war conflict between Begawan Ciptaning or commonly known as Harjuna and Keratarupa who is the incarnation of Bathara Guru. This war is an interpretation of the way they defend the truth and responsibility.

Unlike the original story, which tells about their fight over a wild boar. It is said that they shot and hit the wild boar at the same time, so a dispute arose over who would get the boar. In the Harjuna-Keratarupa dance, there are two characters in the wayang, namely Begawan Ciptaning or Harjuna and Raden Keratarupa. Begawan Ciptaning is meditating on Mount Indrakila. He is called Ciptaning because when he meditates, he always keeps silent thoughts, feelings, and intentions continuously to the gods.

Begawan Ciptaning was forced to stop his meditation because a wild boar snorted and approached, then attacked the place he was meditating. The Begawan was disturbed by the animal attack. Begawan Ciptaning immediately took an arrow and then released it right into the neck of the wild boar. It turned out that Begawan Ciptaning shot an arrow at the same time as Raden Keratarupa's arrow which was also stuck in the neck of the wild boar. The wild boar itself turned out to be the incarnation of Mamang Murka, the prime minister of Prabu Newatakaca King of the Kingdom of Ima (Imantaka). Begawan Ciptaning and Raden Keratarupa fought over the truth about the arrow that hit the wild boar, so a battle broke out. Begawan Ciptaning changed into Raden Harjuna Panengah Pandhawa, and Raden Keratarupa turned into Bathara Guru. From this point of view, the Harjuna-Keratarupa dance was developed. This dance tries to show the point of view of truth and responsibility. The choreographer wanted Harjuna to have a delicate-male character and Keratarupa to have an agile-male character.

\section{The Process of Creating Harjuna-Keratarupa Dance}

Harjuna-Keratarupa dance is one of the dances taken from the Mahabharata story in the play entitled Arjuna Wiwaha. This dance was composed in 1995 to prepare dance performances by ISI Surakarta lecturers to increase the number of performance materials at ISI Surakarta. The first step taken by the choreographer is to choose dancers with the right character, as stated in the book Analisa Gerak dan Karakter by Agus Tasman that:

Dancers are people who present the beauty of their body movements by involving the interpretation of aesthetic ideas in choreography and imagination (Tasman, 2006: 27).

The above statement can be interpreted that the dancer is a means of conveying the message of a dance. Therefore, from there will emerge an atmosphere that supports the dance presentation to lead the audience to be immersed in the dance. Such an achievement is expected by the choreographer so that it does not only convey the sequence of motion or the sequence of the storyline but also contains messages and impressions in the dance presentation. Dancers must also be good at imagining and interpreting a dance to be more beautiful so that the message can be conveyed properly to the audience.

The creation of this dance begins with the introduction and deepening of the characters of Harjuna and Keratarupa. The choreographer places more emphasis on the emotions and feelings that the dancers build. As Pina Bausch puts it:

I'm less interested in how people move, but more interested in what touches the audience's feelings. The choreographer's work does not move from beginning to end but grows from within (me) out (into a form of expression) (Bartlett, 1999: 4).

This statement is in line with the choreographer's principle, which emphasizes more on the feeling that must be raised by the dancer or a form of emotion that is raised and conveyed to the audience so that the audience can better understand the meaning implied in the dance. In dance, the movement technique is also influenced by the way and quality of the dance so that it is pleasing to the eye and comfortable to feel every movement. As Sumandyo Hadi said that:

To achieve movement technique skills, a dancer must understand in detail "form techniques", "medium techniques", and "instrument techniques". The aesthetic unity of form techniques, medium techniques, and instrument techniques must of course be understood as elements that make up dance compositions (Hadi, 2007: 29).

Understanding the concept of form technique, medium technique, and instrument technique, is the knowledge that a dancer needs about dance and technical skills when performing a series of dance moves. So that it is complete when both are combined with good bodily techniques and carried out with a sense that grows from the dancers, making this dance convey the message that the choreographer wants to express.

\section{The Form of Harjuna-Keratarupa Dance Performance}

Harjuna-Keratarupa dance has a form of dance that is different from the Surakarta style dance in general. The choreographic structure of Harjuna-Keratarupa dance consists of ada-ada (opening), perang gendhewa (bow battle), beksan (dance), perang selendang (shawl battle), perang keris (kris battle), perang panahan (archery 
battle), beksan mundur (retreat dance). Dance movements in Harjuna-Keratarupa dance refers to the traditional dance movements of Surakarta and added a variety of Yogyakarta Style dance movements in the beksan section. The battle pattern used is more than one model of warfare, including shawl battle, kris battle, and bow battle.

The structure of the gendhing in this dance uses gendhing kosekan which is usually used in wayang kulit performances, but the choreographer uses the gendhing during beksan and gendhing srepeg during the battle. The gendhing presented is expected to describe and enliven the dance atmosphere.

Harjuna-Keratarupa dance performance displays the form of pethilan (pieces) with two different characters, although they both use a Surakarta-style pliant dance format in their movement structure. Harjuna with a delicate-male character, his movements are gentle but agile, firm, and skilled in combat. Meanwhile, the character of Keratarupa is a male alus lanyap (agile-male), firm, arrogant, authoritative, and skilled in combat. Harjuna-Keratarupa dance uses devices (tools/weapons) in the form of bow and kris.

The makeup used is delicate-male character makeup and agile-male character makeup. Wardrobes used include: black velvet pants, frilled jarik with lereng cokelat motif, cancut, belt, shawl, epek timang, bara-samir, srempang, endhong panah (quiver), nyenyep, irah-irahan gelung luruh, kantong gelung, sumping, klat bahu, binggel, uncal, kalung ulur, necklace (for Harjuna), dan red velvet pants, frilled jarik parang garudha putih, cancut, belt, shawl, epek timang, bara-samir, srempang, probo, irah-irahan gelung lanyap , kantong gelung, sumping, klat bahu, binggel, uncal, kalung ulur, necklace (for Keratarupa).

The composer of Harjuna-Keratarupa dance accompaniment is Takariyadi. The gendhing structure is as follows:

a. Ada-ada Sl.Pelog 6, depicts Harjuna who is meditating and is disturbed by a boar. Then Keratarupa entered and observed Harjuna who was chasing the wild boar. Followed by gendhing Srepeg 3 which describes the battle between Harjuna and the wild boar.

b. Continued with jineman Sri Martono which describes the archery battle between Harjuna and Keratarupa who fought the wild boar, and enters gendhing sampak 3 which describes the wild boar who had been shot by Harjuna and Keratarupa but they fought over claims about whose arrows hit the wild boar, and there was a bow battle between Harjuna and Keratarupa.

c. Ladrang Memasuh then enters Ketawang Lik then moves to Ompak. This gendhing is used for the beksan part.

d. Srepeg 6 is used for shawl battles.

e. Lancaran 2 is used for the kris battle.

f. Gendhing Palaran is used for archery battle.

g. Sampak 2 is used for gendhing mundur beksan until the dancer leaves the stage.

\section{The Development of Harjuna-Keratarupa Dance}

Development is a demand, because this is an effort to adapt to the changing times. This was emphasized by Edi Sedyawati, that:

Culture, including the life of art, must be dynamic to develop according to the times if the culture is to survive amid its supporting community. The era that is always moving and the growing human needs accompany it, making cultural products must be actualized to adapt to these developments. Although actually in the development of culture we cannot forget the cultural roots of the past (Sedyawati, 1984: 39).

Referring to the opinion of Edi Sedyawati above, the intended dynamic is the process of culture or art in following the development of the times and its people. The Harjuna-Keratarupa dance has also undergone several developments since its creation in 1995 until now. Harjuna-Keratarupa dance is experiencing development in sekaran, its composition is also increasing. In addition to dance, gendhing has also developed.

Initially, the Harjuna-Keratarupa dance functioned as a work that was prepared in the context of staging the works of lecturers at the Sekolah Tinggi Seni Indonesia (STSI) Surakarta. However, as time goes by, currently the Harjuna-Keratarupa dance is widely studied or used as a medium for teaching materials for the fifth semester of the delicate-male dance in pairs at the Institut Seni Indonesia (ISI) and as one of the choices for the Surakarta Style delicate-male dance demonstration examination material.

This development can occur in changes in the floor pattern of sekaran both in the motion of the beksan or the ability to control the stage space. These changes aim to reconstruct and reinterpret the existing traditional dances. Changes in the idea of dance compositions also result in a wider variety of work ideas expressed in the form of dance compositions. These developments, of course, still consider the initial interpretation of the dance presentation that is presented, both in terms of the character and the atmosphere to be conveyed. Sal Murgiyanto said that creativity in the frame of tradition does not always mean creating new works, but creativity in making innovations (Murgiyanto, 2007: xii).

It can be seen in several presentations, the Harjuna-Keratarupa dance has undergone several changes and developments from the initial work of the dance, which of course is subject to the interpretation and understanding of each performer. Here are some examples of the development of the Harjuna-Keratarupa dance: 
1) Dwiyasmono and Matheus Wasi Bantolo

Initially, Harjuna-Keratarupa Dance was a performance created by lecturers at the Indonesian College of Arts (STSI) Surakarta. In this performance, the costumes used are human wayang costumes. Harjuna's character looks more delicate. The dancer who brought Harjuna's character was on stage and was in the middle of the stage showing the situation of Harjuna who was meditating.

2) Irwan Dhamasto and Dhestian Wahyu Setyaji

This performance shows the change and rearrangement of the form of motion. Changes were made to the archery movements of the two dancers. and there is a tug-of-war movement of the bow before squeezing in the bow battle section. In the kris battle, there is a change in the motion of the stab. The costumes used are still the human wayang model costumes. These changes were staged in 2017.

3) Damasus Chrismas Verlananda Waskito and Ahmad Saroji at a demonstration exam in Magelang In this performance, Keratarupa came out first and was followed by Harjuna whose motivation was because he saw a wild boar. This change in the shape of the beksan creates the impression of a mutual response between the dancers of Harjuna and Keratarupa. The kris battle was also changed to make it more intense. bow battles are also changed to give the impression of being more skilled.

Describing the dancer's costumes, Harjuna's character does not use gelung luruh but uses jamang and uren. The reason for choosing this costume is because in sanggit of human wayang when Harjuna was meditating, he still used jamang and wore uren. Harjuna has not worn a head accessory in the form of a gelung luruh. This change was performed in 2018 in commemoration of the Mertidusun event in Magelang Regency, Central Java.

\section{Conclusion}

The Harjuna-Keratarupa dance is a dance composition in the form of pethilan (a fragment of a longer story). This dance has a characteristic that is in the form of the Surakarta style delicate dance which the dance moves are combined with the Yogyakarta style delicate dance. This dance features two wayang figures with two different characters. Harjuna with the character of the male-delicate. His movements are delicate but during battles, he is quick, firm, and skilled; while the character of Keratarupa is a male-agile. He is firm, arrogant (cakrak), authoritative, and skilled at wars.

Harjuna-Keratarupa uses bow and kris as dance equipment because this dance emphasizes patterns of war movement. The choreographer got the idea of composing the composition from his interest in the battle scene between Harjuna and Keratarupa. This section tells of a conflict between Begawan Ciptoning who is usually known as Harjuna and Keratarupa who is the incarnation of Bathara Guru. According to the choreographer, this war is an interpretation of the attitude of maintaining the truth and sincerity in carrying out responsibilities.

This dance has undergone many developments. The development occurred in changes in floor patterns, motion sequences in both beksan and battle scenes to be able to control the stage space. These changes aim to reconstruct and reinterpret the existing traditional dances. Changes in the ideas of composition also add to the variety of compositional ideas expressed in the form of dance creations. In Harjuna-Keratarupa, the choreographer places more emphasis on the feeling that the dancer must convey, or a form of emotion that is shown so that the audience can feel it so that the audience can better grasp the implied meaning in the dance.

\section{References}

Aprilina, Finta Ayu Dwi. "Rekonstruksi Tari Kuntulan sebagai Salah Satu Identitas Kesenian Kabupaten Tegal”. Jurnal Seni Tari, Universitas Negeri Semarang. 2014.

Hadi, Y. Sumandyo. Kajian Tari Teks dan Konteks. Yogyakarta: Pustaka Publisher. 2007.

Hastuti, Bekti Budi dan Supriyanti. "Metode Transformasi Kaidah Estetis Tari Tradisi Gaya Surakarta" Jurnal Seni Tari, Institut Seni Yogyakarta. 2015.

Irsyad, Rhona Halidhian. "Perkembangan Bentuk Pertunjukan Kesenian Emprak Kelompok Sido Lancar Desa Plajan Kecamatan Pakis Aji Kabupaten Jepara”. SKRIPSI, Institut Seni Indonesia Surakarta. 2013.

Murgiyanto, Sal. Pertunjukan Budaya dan Akal Sehat. Fakultas Seni Pertunjukan IKJ. 2015.

Saleh. Mahabarata. Jakarta: Balai Pustaka, 1991.

Sedyawati, Edi. Pertumbuhan Seni Pertunjukan, "Seri Esni No.4”. Jakarta: Sinar Harapan. 1981

Sriyadi. "Tari Tradisi Gaya Surakarta”. Jurnal Seni Tari, Institut Seni Indonesia Surakarta. 2014.

Tasman, Agus. Analisa Gerak dan Karakter. Surakarta: ISI Press. 2006.

Yasasusastra, J.Syahban. Mengenal Tokoh Pewayangan. Pustaka Mahardika Yogyakarta. 2011. 